\title{
The Effect of Stigma towards Family Functioning in People Living with HIV/AIDS
}

\author{
Wanda Arista Dana Paramitha ${ }^{1}$, Lifina Dewi Pohan ${ }^{2 *}$ \\ ${ }^{1,2}$ Faculty of Psychology, Universitas Indonesia \\ *E-mail: lifina.dewi@ui.ac.id
}

\begin{abstract}
The aim of the study is to examine the effect of stigma towards family functioning on people living with HIV/AIDS in the daily life context. This study especially tries to examine how stigma can affect the effectiveness of family functioning in people living with HIV/AIDS when they deal with the problem caused by the disease. Stigma is defined as awareness of the potential for social disqualification, rejection, opportunity limitation, and negative view that person will receive when the others know about their illness. Meanwhile, family functioning is defined as ways which family members communicate and work together, which will affect the mental and physical health of family members. This study was quantitative study and use paper and pencil method for the questionnaire. The instruments used were Berger HIV Stigma Scale for stigma measurement and Family Assessment Device for family functioning measurement. Both measurements have been tested for its reliability and validity and were proven to be reliable and valid. The questionnaire was given directly to the participants and it takes 40 minutes to answer all the questions. The total number of participants in this study was 62 people living with HIV/AIDS. The result showed that stigma was associated with the decrease of family functioning among people living with HIV/AIDS $(\beta=-0.36, p<0.05)$. This indicated that when the value of stigma increases the value of the family function will decrease.
\end{abstract}

Keywords: HIV/AIDS; family functioning; self-disclosure; stigma

\section{Introduction}

A family is the basic unit of a community in which individuals grow and develop, both physically and psychologically (Dai \& Wang, 2015). The functions of a family are giving various lessons and giving understanding to individuals related to values, beliefs, attitudes, knowledge, and skills that must be acquired. This function can be seen through interaction with family members (Berns, 2013). During the interaction among family members, there is an exchange of information that aims to deepen and develop the relationship (Wisnuwardhani \& Mashoedi, 2012; Miller, 2011). According to the previous study, there are two forms of information: verbal and non-verbal information. The verbal information is something that directly spoken by the individual, while non-verbal information is all things shown by an individual, such as tattoos, dressing, jewelry, and so forth
(Greene, Derlega, \& Mathews, 2006). Pleasant or good information is more likely received by the family. Meanwhile, the unpleasant information is less likely received by the family.

People living with HIV / AIDS (PLWHA) will experience difficulties in communicating information about their condition to the family. They are afraid that they will not be accepted by the family. This can happen because the information they want to convey is information that already has a negative outlook to the community and the individuals do not want their family is thrown away or embarrassed (Songwathana \& Manderson, 2001). The negative views that often associated with PLWHA happened because the community already has a certain standard about a certain matter within the society, commonly called the stigma (Goffman, 1963). Stigma appears when the individual is aware that there is potential for social disqualification, rejection, limitation of 
opportunity, and the negative view they will receive when others know their condition (Berger, Ferrans, \& Lashley, 2001). The stigma received by PLWHA and their family or can cause stress to the PLWHA ( $\mathrm{Li}, \mathrm{Wu}, \mathrm{Wu}$, Jia, Lieber, \& Lu, 2008). This stress appears because of several factors such as the concerns about the disease itself, the cost of the disease, the fear of stigma and discrimination, the fear of others will know the status, and the feelings of guilt to the family (Li, et al., 2008; Petrak, Doyle, Smith, Skinner, \& Hedge, 2001).

A study in China conducted by Li, Li, Ji, Sun and Rotheram-Borus (2009) on 116 HIV-infected parents who have at least one child, indicates that people living with HIV do not want to reveal their status to others because people living with HIV are afraid of losing their jobs and a place of residence that they already have. They also afraid if people know about their status then their family members will also lose their jobs and be shunned by others. The similar result was also found in the research conducted by Gielen, Fogarty, O'Campo, Anderson, Keller, and Faden, (2000) who found the main reason people living with HIV did not disclose their status to others because, HIVpositive people are afraid of losing their income resources, and are afraid being "discarded" by the community where they live.

The stigma given by the community to PLWHA occurs because people know that people living with HIV have a virus, known as human immunodeficiency virus (HIV) that can be transmitted. This virus can weaken the immune system in people living with HIV, therefore people living with HIV are very vulnerable to diseases (WHO \& ILO, 2005). Also, the stigma also arises because of unprotected sex and the use of drugs with the same syringe in turn (Duffy, 2005; Simbayi, Kalichman, Strebel, Cloete, Henda, \& Mqeketo, 2007).

$\mathrm{Li}$, et al. (2008) describes the stigma that often appears will be experienced by both PLWHA and their families. In the country with collectivism culture, the family will be blamed for the condition of the family members who are infected with HIV. The family is considered incapable of taking care of its family members. On the other hand, the family will also get discrimination and negative views because all of the family members will be associated with PLWHA, which is considered by the society to violate norms and standards that exist in the community.

The negative views felt by families can affect the family's social relationships with PLWHA and people around them. When a family member knows that one of their family members is PLWHA, they tend to starts to move away from PLWHA. In some cases, they even do not want to mention the name of PLWHA in their social interaction, because they are embarrassed and do not want anyone else to see them or associate them with the PLWHA (Li, et al., 2008). This rejection occurs because of the lack of knowledge about HIV disease transmission, causing PLWHA choose not to disclose their status to their families (Petrak, et al., 2001). In a study conducted by Bogart, Cowgill, Kennedy, Ryan, Murphy, Elijah, and Schuster (2008) among American family, the rejection of PLWHA is shown by the act of avoiding using the same utensils that have been used by PLWHA.

Li et al. (2008) found some variety of responses that appeared to families when they found out that there were members of the family who were infected with HIV. There are families who cannot cope with the changes that occur, cannot overcome the stigma of the community, and cannot overcome the problems caused by PLWHA. The family who cannot cope with the problems and consequences of PLWHA, tend to experience family disruption, such as nonvoluntary communication due to family reluctance to discuss HIV, not getting help from other parties, the family loses relationships with other people who have good relationships, and the absence of family involvement in PLWHA life (Bogart, et al., 2008). Furthermore, the negative responses will cause the PLWHA reluctant to open themselves to the family.

In contrast, Miller (2011) explains that positive responses which received by PLWHA when an individual opens themselves to others, will lead to a positive feeling towards their decision. This will encourage them to be more open to others. In addition, the families who try to overcome the problems together with PLWHA is to be able to function effectively.

The relationship in the family can be seen from the process of family functioning. Family functioning is a reflection of family activities and interactions, and it plays an important role in developing its family members (Walsh, 2003). Family functioning can be seen from two different viewpoints; first, the points of view of the results obtained and second the viewpoint of the process that occurs in the family. Both of these points of view have a purpose to determine how healthy or functioning a family is (Dai \& Wang, 2015). In this study, the researchers will see the functioning of the family based on the perspective of the 
process that occurs in the family. Dai \& Wang (2015) explains there are two major theories that look at families based on the viewpoint of the processes that occur within the family namely McMaster Family Functioning Mode Theory and Skinner's Family Process Model Theory. Skinner's Family Process Model Theory emphasizes the interaction of relationships between family members and the interactions they have for the whole family. McMaster Family Functioning Model Theory, see the processes that family systems as the core of the family. The theory explains that the family has a basic function that must be fulfilled, which is to provide a good environment to family members to develop physical, psychological, social, and other aspects. Based on the description above the researcher has a hypothesis that the stigma felt by PLHIV can affect the functioning of PLHIV family.

\section{Methods}

Sample. This study was conducted to 62 people who were positive HIV/AIDS infected. Inclusion criteria for our sample were (a) aged 20-60 years old, (b) have received a minimum education to Junior High School (JHS), and (3) currently live in the Jabodetabek area. Participants were obtained from several foundations or non-government organizations that working for people with HIV / AIDS in the area of Jakarta and Depok.

Research Design. This study is a quantitative study which measures the variable from the total score of each variable (Gravetter \& Forzano, 2011).

Instrument and Measurement. Berger HIV Stigma Scale was developed by Barbara R. Berger, Carol Estwig, and F. Lashley (2001). This instrument was used to measure stigma of people living with HIV/AIDS (PLWHA).This instrument has 40 items. Each item was rated on a four-point scale. The instrument used in this study has been adapted to the Indonesian language by Nurdin (2013). In a study conducted by Nurdin (2013) coefficient correlation alpha is 0.94 and coefficient correlation alpha for sub-scales is 0.81-0.92. This instrument measured how PLWHA internalized stigma given by others. There are four dimensions in this instrument: internalized stigma, disclosure concern, negative self-image, and people attitude toward people living with HIV/AIDS.

Family Assessment Device. It was developed by Epstein, Baldwin, and Bishop (1983). This instrument is used to measure family functioning in people living with HIV/AIDS (PLWHA). This instrument has 49 items. Each item was rated on a four-point scale. This study used the instrument that had been adapted to the Indonesian language by Murti (2013). The study conducted by Murti found that the coefficient correlation alpha of this instrument is 0.88. Family Assessment device consists of seven dimensions: problem-solving, communication, roles, affective response, affective involvement, behavioral control, and general functioning.

Procedure. The Data collection was conducted at foundations or non-governmental organizations covering people with HIV/AIDS. The participants have been informed by workers in the foundation or non-governmental organization. Participants were asked to fill the questionnaires given by the researcher.

\section{Results}

The total number of participants in this study was 62. The participants consisted of $68.3 \%$ females and $31.7 \%$ males. The majority of the participants are graduates from senior high school level $(65.1 \%)$. The Majority of participants lived with their family $(84.1 \%)$, the majority of participants informed their status to family and friends (47.6\%), and most of the participant was already infected with HIV for more than four years (71.4\%).

Table 1.

Demographic Data

\begin{tabular}{|c|c|}
\hline Characteristic & Percentage $(\%)$ \\
\hline \multicolumn{2}{|l|}{ Gender } \\
\hline Man & $31.7 \%$ \\
\hline Woman & $68.3 \%$ \\
\hline \multicolumn{2}{|l|}{ Age } \\
\hline $17-22$ & $1.6 \%$ \\
\hline $22-28$ & $15.9 \%$ \\
\hline $28-33$ & $28.6 \%$ \\
\hline $33-40$ & $41.3 \%$ \\
\hline $40-45$ & $11.1 \%$ \\
\hline $45-50$ & $1.6 \%$ \\
\hline \multicolumn{2}{|l|}{ Education } \\
\hline Junior High School & $12.7 \%$ \\
\hline Senior High School & $65.1 \%$ \\
\hline Diploma & $7.9 \%$ \\
\hline Bachelor Degree & $9.5 \%$ \\
\hline Master Degree & $1.6 \%$ \\
\hline No Answer & $1.6 \%$ \\
\hline \multicolumn{2}{|l|}{ Living Arrangement } \\
\hline Living alone & $15.9 \%$ \\
\hline Living with family & $84.1 \%$ \\
\hline \multicolumn{2}{|l|}{ Infected } \\
\hline$<4$ years & $28.6 \%$ \\
\hline$>4$ years & $71.4 \%$ \\
\hline
\end{tabular}


The effect of stigma on family functioning was measured using simple regression analysis. The result from the study found that stigma has a negative effect on family functioning $(\beta=-0.36, p$ $<0.05)$. The results also showed that stigma scores accounted for $14 \%$ of the variance in family functioning scores $\left(\mathrm{R}^{2}=0.14 . p<0.05\right)$.

Table 2.

Result Stigma on Family Functioning

\begin{tabular}{lr}
\hline Family Functioning & $-0,36^{*}$ \\
\hline Stigma & 0,14 \\
$\mathbf{R}^{2}$ & \\
\hline *significant $p<0,05$ &
\end{tabular}

\section{Discussion \& Conclusion}

Discussion. This study found that the stigma has a negative effect on the family functioning of PLWHA, that means the higher score of the stigma will follow the lower score of family functioning. The result was similar to the study conducted by Bogart, et al., (2008). It was found that the stigma felt by PLWHA affects the family functioning. The stigma that received by PLWHA's families affects families in various ways, such as how families deal with current problems, how the family members interact with each other, the interaction with people around them, and family rules.

Significant negative effects also occur in the personalized stigma dimensions and dimensions of affective response. This indicated that the support from the family would reduce the negative feelings that PLWHA received from stigma given by the community. A study conducted by Ryan, Epstein, Keitner, Miller, and Duane (2005) shown that the affective responses are the way families respond appropriately to stimuli (in this case the stories or information submitted by family members) delivered by family members. In this study when the affective response given to PLWHA is good or as expected, the personalized stigma perceived by PLWHA will be lower. Thus, responses such as support, warmth, and understanding will reduce the effect of the stigma (Ryan, et al., 2005; Salter, Go, Minh, Gregowski, Ha, Rudolph, Latkin, Celentano, \& Quan, 2010).

The study by Salter et al. (2010) found that PLWHA who has informed the family of their status and the family is providing support and assisting PLWHA, will have the desire to care for the illness and continue to live their life. The researchers assumed that these two dimensions could have a significant effect. PLWHA who told their family will get support from the surrounding environment in facing the stigma from others or stigma within themselves.

Furthermore, our study found that the behavior control dimension on family functioning has a significant negative correlation with the personalized stigma dimension and the dimension of concern with Public Attitude toward People Living with HIV. Bogart et al. (2008) in his research found that PLWHA who have children will consider carefully about the decision to notify their status to their children. The reason is that PLWHA is afraid that the discrimination will happen to their children. This discrimination arises from the fear of HIV transmission from PLWHA (Salter et al., 2010). When the parents have decided to tell their children about their status, then the parents set the rules and prohibit their child to tell the status of their parents to their friends. Researchers assumed that when the parents or the families have agreed on the rules, they have to live, their anxiety about how people views themselves will decrease. The possible explanation is because they believe that the family will comply with the rules that have been set out and will not carelessly tell their family status to others.

In this study, the authors realize that there are still some limitations of this research, including the age range of participants are not equal. In this study, the participants who are in the age range of 20-40 years is more than the participants at the age of more than 40 years. The researchers also do not differentiate the severity of illness experienced by the participants whereas this can affect the stigma felt by participants. The suggestion for future study is to explore more variables related to stigma and family functioning on people living with HIV/AIDS (PLWHA), such as severity of the illness and the time spent for the participants to know about their condition.

Conclusions. Based on the analysis and interpretation of the results, the researcher can conclude that stigma has a negative effect on the family functioning of PLWHA. This means that when the increase in the value of stigma is followed by the decreased value of the family functioning.

\section{References}

Berger, B. E., Ferrans, C. E., \& Lashley, F. R. (2001). Measuring stigma in people with HIV: Psychometric assessment of the HIV stigma scale. Research in nursing \& health, 24(6), 518-529. 
Berns, R. M. (2013). Child, Family, School, Community: Socialization and Support, Ninth Edition. Wadsworth: Cengage Learning.

Bogart, L. M., Cowgill, B. O., Kennedy, D., Ryan, G., Murphy, D. A., Elijah, J., \& Schuster, M. A. (2008). HIV- related stigma among people with HIV and their families: A qualitative analysis. AIDS and Behavior, 12(2), 244-254.

Dai, L., \& Wang, L. (2015). Review of family functioning. Open Journal of Social Sciences, 2015 (3), 134-141 http://dx.doi.org/10.4236/jss.2015.312014.

Epstein, N. B., Baldwin, L. M., \& Bishop, D. S. (1983). The McMaster family assessment device. Journal of Marital and Family Therapy 9(2), 171-180.

Duffy, L. (2005). Suffering, shame, and silence: The stigma of HIV/AIDS. Journal of The Association of Nurses in AIDS Care 16(1), 13-20 doi:10.1016/j.jN.2004.11.002.

Gielen, A. C., Fogarty, L., O’Campo, P., Anderson, J., Keller, J., \& Faden, R. (2000). Women living with HIV: Disclosure, violence, and social support. Journal of Urban Health 77(3).

Goffman, E. (1963). Stigma: Notes on the Management of Spoiled Identity. New York: Penguin Books.

Gravetter, F. J., \& Forzano, L. B. (2011). Research Methods for the Behavioral Sciences, Fourth Edition. Wadsworth: Cengage Learning.

Greene, K., Derlega, V. J., \& Mathews, A. (2006). Cambridge Handbook of Personal Relationships. Cambridge: Cambridge University Press.

Kumar, R. (2011). Research Methodology, Third Edition. New Delhi: Sage Publications India Pvt Ltd.

Li, L., Li, C., Ji, G., Sun, S., \& Rotheram-Borus, M. J. (2009). Parents living with HIV in China: Family functioning and quality of life. Jurnal Child Family Studies 18, 93-101 doi: 10.1007/s10826-008-9210-5.

Li, L., Wu, Z., Wu, S., Jia, M., Lieber, E., \& Lu, Y. (2008). Impacts of HIV/AIDS stigma on family identity and interactions in China. Families, Systems, \& Health 26(4), 431-442 doi: 10.1037/1091-7527.26.4.431.
Miller, R. S. (2011). Intimate Relationships, Sixth Edition. New York: McGraw-Hill Education.

Murti, R. A. (2013). Hubungan antara family funcioning dan keterlibatan dalam perilaku bullying pada siswa SMA [SKRIPSI]. Depok: Universitas Indonesia.

Nurdin, A. C. (2013). Uji validitas dan reliabilitas Berger HIV Stigma Scale versi Bahasa Indonesia dalam menilai perceived stigma pada orang dengan HIV/AIDS (ODHA) [TESIS]. Depok: Universitas Indonesia.

Petrak, J. A., Doyle, A., Smith, A., Skinner, C., \& Hedge, B. (2001). Factors associated with self-disclosure of HIV serostatus of significant others. British Journal of Health Psychology (6), 69-79.

Ryan, C. E., Epstein, N. B., Keitner, G. I., Miller, I. W., \& Duane, S. B. (2005). Evaluating and Treating Families: The McMaster Approach. New York: Taylor \& Francis Group, LLC.

Salter, M. L., Go, V. F., Minh, N. L., Gregowski, A., Ha, T. V., Rudolph, A., Latkin, C., Celentano, D. D., \& Quan, V. M. (2010). Influence of perceived secondary stigma and family on the response to HIV infection among injection drug users in Vietnam. AIDS Education and Prevention, 22(6), 558-570

Simbayi, L. C., Kalichman, S., Strebel, A., Cloete, A., Henda, N., \& Mqeketo A. (2007). Internalized stigma, discrimination, and depression, among men and women living with HIV/AIDS in Cape Town, South Africa. Social Science \& Medicine 64, 18231831. doi: 10.1016/j.socscimed.2007.01.006.

Songwathana, P., \& Manderson, L. (2001). Stigma and rejection: Living with AIDS in villages in southern Thailand. Medical Anthropology, 20(1), 1-23.

Walsh, F. (2003). Normal Family Processes: Growing Diversity and Complexity. New York: Guilford Press.

WHO \& ILO. (2005). Pedoman Bersama ILO/WHO tentang Pelayanan Kesehatan dan HIV/AIDS. Jakarta: Direktorat Pengawasan Kesehatan Kerja.

Wisnuwardhani, D., \& Mashoedi, S. F. (2012). Hubungan Interpersonal. Jakarta: Penerbit Salemba. 